\title{
PENGARUH JENIS PENGEMAS DAN LAMA PENYIMPANAN TERHADAP MUTU PRODUK NUGGET GEMBUS
}

\author{
Achmad Furqon A. Q, Iffan Maflahah, Askur Rahman \\ Prodi Teknologi Industri Pertanian, Fakultas Pertanian, UTM \\ Korespondensi : Jalan Raya Telang PO.BOX 2 Kamal - Bangkalan
}

\begin{abstract}
Nugget gembus merupakan produk olahan berbahan baku utama tempe gembus dan mengalami sedikit modifikasi yaitu terdapat penambahan teri nasi dengan perbandingan 3:1. Nugget gembus mudah rusak pada kondisi tertentu, oleh sebab itu diperlukan penelitian yang dapat mencegah rusaknya nugget. Tujuan dari penelitian ini adalah mengetahui pengaruh jenis pengemas plastik dan lama penyimpanan terhadap mutu nugget. Jenis plastik yang digunakan adalah plastik PE (Polietilen) dan PP (Polipropilen) dengan ketebalan masing-masing 0,5 $\mathrm{mm}$. Metode penelitian menggunakan 3 perlakuan yaitu nugget tanpa kemasan, nugget dengan pengemas PE dan nugget dengan pengemas PP. Parameter uji yaitu uji kadar air, uji kadar protein dan uji organoleptik (kerusakan) pada nugget dengan lama penyimpanan selama 30 hari. Nugget disimpan di lemari es menggunakan suhu 100C dengan pengemas plastik dalam kondisi vakum (hampa udara). Uji kadar air menunjukkan jenis plastik PE mampu mempertahankan kandungan air nugget gembus selama 20 hari. Uji kadar protein menunjukkan jenis plastik PP mampu menjaga kadar protein nugget gembus selama 20 hari. Uji organoleptik nugget menunjukkan plastik jenis PP mampu mempertahankan rasa, aroma, tekstur dan warna nugget dari kerusakan sampai hari ke 20.
\end{abstract}

Kata kunci: Nugget gembus, polietilen, polipropilen, lama penyimpanan, mutu.

\section{PENDAHULUAN}

Nugget adalah jenis makanan cepat saji yang biasanya berasal dari olahan daging dan tepung terigu yang dipadatkan kemudian disajikan dengan cara digoreng. Menurut Ginting (2006) Nugget adalah hasil olahan daging hewan berupa campuran daging dan bahan-bahan yang lain seperti rempah-rempah sebagai bumbu kemudian dibuat adonan dan diletakkan pada loyang setelah diratakan dengan ketebalan $1 \mathrm{~cm}$.

Nugget gembus merupakan produk olahan berbahan baku utama tempe gembus dan mengalami sedikit modifikasi yaitu terdapat penambahan teri nasi. Penambahan teri nasi bertujuan menambah cita rasa nugget serta mampu meningkatkan kadar protein nugget. Perbandingan komposisi tempe gembus dengan teri nasi adalah 3:1. Namun, kandungan gizi nugget seperti air dan protein akan mudah mengundang bakteri patogen sehingga merusak mutu dan kandungan gizi nugget gembus. Sehingga, diperlukan penanganan lebih lanjut salah satunya dengan cara pengemasan.

Jenis plastik yang digunakan sebagai pengemas pada penelitian adalah jenis plastik Polietilen (PE) dan Polipropilen (PP). Hal ini dikarenakan kemasan tersebut memiliki kerapatan yang tinggi, tahan terhadap suhu dan kelembapan, serta memiliki daya serap air yang rendah sehingga mampu melindungi produk nugget. Selain itu, plastik memiliki keunikan dalam penampilan fisik yaitu sifatnya yang sangat elastis, memiliki warna yang transparan sehingga produk akan terlihat dari luar kemasan. Berdasarkan kelebihan tersebut pemilihan pengemas plastik menjadi faktor yang sangat penting untuk melindungi mutu produk nugget. 


\section{METODE}

\section{Alat dan Bahan}

Peralatan yang digunakan adalah

Oven, mortar, cawan, erlenmeyer, pipet tetes, pipet volum, gelas ukur, beaker glass, biuret, piring, pisau, dan kompor. Bahan yang digunakan adalah nugget gembus, polietilen (PE) dan polipropilen (PP) dengan ketebalan $0,5 \mathrm{~mm}, \mathrm{NaOH}$, formaldehide, K-Oksalat jenuh, Indikator PP dan aquadest.

\section{Prosedur Penelitian}

Penelitian dimulai dengan pembuatan nugget gembus. Perbandingan tempe gembus dengan teri nasi adalah 3:1 kemudian dicetak membentuk persegi dengan ketebalan $2 \mathrm{~cm}$. Nugget disimpan dalam lemari es dengan suhu $100 \mathrm{C}$ dengan tiga perlakuan yaitu Tanpa Kemasan, Polietilen $0,5 \mathrm{~mm}$ dan Polipropilen 0,5 $\mathrm{mm}$. Selama penyimpanan plastik dalam kondisi vakum (hampa udara). Penelitian dilakukan selama 30 hari. Pengamatan dilakukan tiap lima hari sekali. Pengujian yang dilakukan adalah uji kadar air metode oven, uji kadar protein metode titrasi formol, dan uji organoleptik (kerusakan) pada warna, aroma, rasa, dan tekstur.

\section{HASIL DAN PEMBAHASAN}

\section{Kadar Air}

Jenis kemasan plastik menunjukkan adanya pengaruh yang signifikan terhadap kadar air nugget, akan tetapi jenis kemasan PE dan PP tidak berbeda nyata terhadap kadar air nugget. Tabel 4.1 menunjukkan bahwa jenis plastik PE memiliki kadar air lebih rendah dibandingkan dengan jenis plastik PP. Namun, kadar air jenis PE belum memenuhi standart SNI sebesar $60 \%$.

Tabel 1.Rata - Pengaruh Jenis Kemasan Terhadap Kadar Air Nugget

\begin{tabular}{cc}
\hline Jenis Kemasan & Rata-Rata $(\%)$ \\
\hline Tanpa Pengemas & $34,957 \mathrm{a}$ \\
PE & $67,972 \mathrm{~b}$ \\
PP & $69,697 \mathrm{~b}$ \\
\hline
\end{tabular}

Plastik jenis PP seharusnya lebih baik dalam mempertahankan kadar air nugget karena memiliki permeabilitas uap air yang rendah dari pada PE. Menurut Mareta dan sofia (2011) bahwa permeabilitas plastik polipropilen lebih kecil dibandingkan plastik polietilen sehingga uap air akan lebih sulit menembus plastik polipropilen dari pada polietilen.

Namun, menurut penelitian yang dilakukan oleh Fajrin (2000) Meskipun permeabilitas uap air dan gas plastik PP lebih kecil dari plastik PE, tetapi jika diukur berdasarkan skala 1-10 permeabilitas plastik PP dan PE terhadap uap air, gas, dan bau adalah sama. Meskipun Tabel 4.1 menunjukkan kadar air nugget PE lebih rendah dari PP, tetapi perbedaan tersebut tidak berbeda nyata.

Tabel 2. Rata-Rata Pengaruh Lama Penyimpanan Terhadap Kadar Air

\begin{tabular}{cc}
\hline $\begin{array}{c}\text { Lama Penyimpanan } \\
\text { (Hari) }\end{array}$ & $\begin{array}{c}\text { Rata-Rata } \\
(\%)\end{array}$ \\
\hline 0 & $69,09 \mathrm{c}$ \\
5 & $58,8 \mathrm{~b}$ \\
10 & $59,048 \mathrm{~b}$ \\
15 & $51,452 \mathrm{a}$ \\
20 & $49,321 \mathrm{a}$ \\
\hline
\end{tabular}

Pada pengemas jenis PE, hari ke 5 sampai hari ke 15 mengalami penurunan kadar air, dan pada hari ke 20 mengalami kenaikan kembali. Hal itu disebabkan oleh suhu dan kelembaban yang tidak stabil selama penyimpanan, sehingga nugget mengeluarkan banyak air untuk mencapai kesetimbangan dan menyesuaikan dengan perubahan suhu dan kelembaban. Hal ini sejalan dengan penelitian Latifa (2010) selama penyimpanan seharusnya terjadi peningkatan kadar air, tetapi pada kondisi tertentu dapat mengalami penurunan. Hal itu bisa terjadi karena adanya peningkatan suhu dan adanya penurunan kelembaban, sehingga menyebabkan perpindahan uap air dari bahan ke lingkungan, akhirnya kadar air pada bahan menurun.

\section{Kadar Protein}

Menurut Sulchan dan Endang (2007) 100 gr tempe gembus mengandung sekitar $4,07 \mathrm{~g}$ protein. Setelah dilakukan uji, 
kandungan protein nugget tersebut mencapai $45 \%$ dari total adonan yang di buat. Peningkatan kadar protein pada nugget gembus dimungkinkan dari penambahan teri nasi di dalam adonan.

Selain itu, penggunaan telur sebagai pelapis nugget diduga mampu menambah kadar protein pada nugget. Jenis kemasan memiliki pengaruh yang signifikan terhadap kadar protein nugget gembus. Plastik jenis PP mampu mempertahankan kadar protein nugget lebih baik dibandingkan plastik jenis PE dan perlakuan tanpa kemasan. Tetapi, semua perlakuan mampu mempertahankan kadar protein diatas standar SNI yang ditetapkan sebesar $15 \%$.

Tabel 3. Pengaruh Jenis Kemasan Terhadap Rata-Rata Kadar Protein Nugget Gembus Basis Basah dengan Cara Titrasi Formol

\begin{tabular}{cc}
\hline Jenis kemasan & Rata-Rata $(\%)$ \\
\hline Tanpa Pengemas & $23,931 \mathrm{a}$ \\
PE & $27,434 \mathrm{~b}$ \\
PP & $29,474 \mathrm{~b}$ \\
\hline
\end{tabular}

Kadar protein pada nugget gembus mengalami penurunan. Penyebab penurunan kadar protein adalah terdapat pengaruh mikroorganisme yang ada pada nugget.

Menurut Agus et al. (2013) terdapat kecenderungan penurunan kadar protein akibat dari semakin lama waktu penyimpanan. Penurunan tersebut diduga karena terdapat aktivitas bakteri proteolitik yang dapat mencerna protein. Hal ini didukung oleh penelitian yang dilakukan oleh Creniewicz (2006) bakteri proteolitik dapat tumbuh optimal pada suhu ruang, tetapi masih bisa tumbuh dan berkembang seiring bertambahnya waktu pada suhu lemari es, sehingga dapat menyebabkan degradasi protein. Jumlah bakteri yang ada pada pengemas berkaitan erat dengan permeabilitas plastik. Bakteri proteolitik tergolong bakteri aerobik yang akan tumbuh maksimal dengan adanya oksigen. Semakin banyak oksigen dalam lingkungan maka semakin optimal pertumbuhan bakteri proteolitik.

Plastik jenis PP lebih baik dalam mempertahankan kandungan protein karena permeabilitas plastik PP terhadap gas yang lebih rendah dari pada PE, sehingga menyebabkan protein nugget berkurang lebih sedikit dari pada PE karena mampu menahan gas masuk ke media penyimpanan sehingga menyebabkan berkurangnya proses oksidasi yang mendukung pertumbuhan bakteri. Nugget tanpa pengemas kehilangan kandungan protein lebih banyak dikarenakan tidak adanya pelindung yang mampu menghambat pertumbuhan bakteri.

Tabel 4. Pengaruh Lama Penyimpanan Terhadap Kadar Protein Nugget Gembus Basis Basah dengan Cara Titrasi Formol

$$
\text { Lama Rata-Rata }
$$

\begin{tabular}{|c|c|}
\hline $\begin{array}{l}\text { Penyimpanan } \\
\text { (Hari) }\end{array}$ & $(\%)$ \\
\hline 0 & $45,237 \mathrm{c}$ \\
\hline 5 & $32,588 \mathrm{~b}$ \\
\hline 10 & $20,917 \mathrm{a}$ \\
\hline 15 & $18,969 \mathrm{a}$ \\
\hline 20 & $17,027 \mathrm{a}$ \\
\hline
\end{tabular}

Tabel 4. menunjukkan kadar protein nugget mengalami penurunan seiring dengan lama penyimpanan pada produk nugget. Pada hari ke 0 sampai hari ke 20 bakteri mengalami pertumbuhan secara terus menerus, sehingga secara langsung mengurangi kadar protein nugget. Menurut Marada (2012) bakteri akan mengalami fase logaritmik seiring lama penyimpanan. Fase pertumbuhan logaritmik adalah fase dimana bakteri membelah dengan cepat dan konstan mengikuti kurva logaritmik.

Prinsip dari titrasi formol menurut Sudarmaji et.al. (2003) adalah mengikat asam amino yang dalam hal ini mewakili jumlah protein kemudian di titrasi dengan $\mathrm{NaOH}$ menggunakan indikator PP sampai diperoleh nilai $\mathrm{N}$ untuk mengetahui kadar protein. Titrasi formol menunjukkan proses terjadinya pemecahan protein dan tidak bisa menentukan jenis protein.

Tabel 5. menunjukkan perlakuan tanpa pengemas mengalami penurunan kadar protein yang sangat drastis karena tidak adanya pelindung yang mampu menghambat proses oksidasi selama penyimpanan sehingga bakteri tumbuh optimal. Semakin berkurang nilai protein menunjukkan semakin tinggi pula proses hidrolisis protein yang terjadi. Bakteri memecah asam amino menjadi senyawa yang lebih sederhana sehingga kadar protein menurun. 
Perlakuan PE dan lama penyimpanan ke-10 terjadi penurunan kadar protein yang mencolok, kemudian pada hari ke 15 mengalami kenaikan kembali. Hal tersebut diduga karena komposisi dari bahan tambahan nugget pada hari ke 10 yaitu teri nasi tidak tercampur rata. Menurut Istanti (2005) adanya perubahan kadar protein pada pangan juga disebabkan oleh proses pengadukan yang kurang kalis saat pembuatan adonan. Sehingga bahan pada adonan tidak bercampur rata dan tidak homogen.

\section{Uji Organoleptik}

Uji organoleptik pada penelitian ini menggunakan sistem perseorangan. Pengujian dilakuan dengan cara mengamati perubahan pada nugget dimulai pada hari ke nol sampai nugget mengalami kerusakan. Jenis kerusakan yang diamati meliputi tekstur, aroma, rasa, dan warna.

Tabel 6. menunjukkan perlakuan tanpa kemasan pada hari ke 0 sampai hari ke 10 memiliki rasa yang masih sangat baik. Namun pada hari ke 15 sampai hari ke 20 nugget gembus mulai mengalami kerusakan yaitu nugget sudah mulai tidak ada rasa. Perubahan tersebut dikarenakan nugget mengalami kehilangan banyak air. Kerusakan tersebut ditandai dengan perubahan rasa dari asin menjadi hambar. Aroma khas ikan menjadi tanpa aroma. Tekstur pada hari ke nol lembut dan kenyal menjadi keras dan kaku. Warna berubah dari coklat cerah menjadi coklat tua. Rata-rata perlakuan normal mengalami kerusakan fisik pada hari ke 15 .

Tabel 5. Pengaruh Jenis Pengemas dan Lama Penyimpanan Terhadap Kadar Protein Nugget Gembus Basis Basah dengan Cara Titrasi Formol

\begin{tabular}{llll}
\hline $\begin{array}{c}\text { Lama } \\
\text { Penyimpanan } \\
\text { (Hari) }\end{array}$ & Tanpa Pengemas & $\begin{array}{l}\text { Perlakuan } \\
\text { PE }\end{array}$ & PP \\
\hline $0(\%)$ & $45,237 \mathrm{e}$ & $45,237 \mathrm{e}$ & $45,237 \mathrm{e}$ \\
$5(\%)$ & $36,480 \mathrm{~d}$ & $29,183 \mathrm{~cd}$ & $32,100 \mathrm{~d}$ \\
$10(\%)$ & $20,430 \mathrm{bc}$ & $18,970 \mathrm{bc}$ & $23,350 \mathrm{c}$ \\
$15(\%)$ & $13,130 \mathrm{~b}$ & $20,430 \mathrm{bc}$ & $23,347 \mathrm{c}$ \\
$20(\%)$ & $4,380 \mathrm{a}$ & $23,350 \mathrm{c}$ & $23,350 \mathrm{c}$ \\
\hline
\end{tabular}

Ket: Huruf yang sama menunjukkan tidak berbeda nyata

Tabel 6. Uji Organoleptik Nugget Gembus

\begin{tabular}{|c|c|c|c|c|c|c|c|c|c|c|c|c|}
\hline \multirow{3}{*}{$\begin{array}{l}\text { Lama } \\
\text { penyim- } \\
\text { panan } \\
\text { (hari) }\end{array}$} & \multicolumn{12}{|c|}{ Perlakuan } \\
\hline & \multicolumn{4}{|c|}{ Tanpa pengemas } & \multicolumn{4}{|c|}{ Kemasan Plastik PE } & \multicolumn{4}{|c|}{ Kemasan Plastik PP } \\
\hline & Rasa & $\begin{array}{l}\text { Aro- } \\
\text { ma }\end{array}$ & $\begin{array}{l}\text { Teks } \\
\text {-tur }\end{array}$ & Warna & Rasa & $\begin{array}{l}\text { Aro- } \\
\text { ma }\end{array}$ & Tekstur & warna & rasa & $\begin{array}{l}\text { Aro- } \\
\text { ma }\end{array}$ & Tekstur & $\begin{array}{l}\text { war } \\
\text { na }\end{array}$ \\
\hline 0 & $\begin{array}{l}+++ \\
++\end{array}$ & $\begin{array}{l}+++ \\
++\end{array}$ & $\begin{array}{l}+++ \\
++\end{array}$ & $\begin{array}{l}++++ \\
+\end{array}$ & $\begin{array}{l}+++ \\
++\end{array}$ & $\begin{array}{l}++++ \\
+\end{array}$ & +++++ & $\begin{array}{l}++++ \\
+\end{array}$ & $\begin{array}{l}++ \\
++ \\
+\end{array}$ & $\begin{array}{l}++++ \\
+\end{array}$ & +++++ & $\begin{array}{l}+++ \\
++\end{array}$ \\
\hline 5 & $\begin{array}{l}+++ \\
++\end{array}$ & $\begin{array}{l}+++ \\
++\end{array}$ & $\begin{array}{l}+++ \\
++\end{array}$ & +++ & $\begin{array}{l}+++ \\
++\end{array}$ & $\begin{array}{l}++++ \\
+\end{array}$ & +++++ & ++++ & $\begin{array}{l}++ \\
++ \\
+\end{array}$ & $\begin{array}{l}++++ \\
+\end{array}$ & +++++ & $\begin{array}{l}+++ \\
+\end{array}$ \\
\hline 10 & $\begin{array}{l}+++ \\
++\end{array}$ & $\begin{array}{l}+++ \\
+ \\
\end{array}$ & $\begin{array}{l}+++ \\
+ \\
\end{array}$ & +++ & $\begin{array}{l}+++ \\
+ \\
\end{array}$ & ++++ & +++++ & ++++ & $\begin{array}{l}++ \\
+\end{array}$ & +++ & +++++ & $\begin{array}{l}+++ \\
+ \\
\end{array}$ \\
\hline 15 & + & + & ++ & +++ & +++ & ++ & +++++ & ++++ & ++ & ++ & +++++ & $\begin{array}{l}+++ \\
+\end{array}$ \\
\hline 20 & + & + & + & +++ & ++ & + & +++ & ++++ & ++ & + & ++ & $\begin{array}{l}+++ \\
+ \\
\end{array}$ \\
\hline
\end{tabular}

Ket: Tanda Plus (+) menunjukkan tingkat mutu nugget gembus, +5=Sangat Baik, +4=Agak Baik, $+3=$ Cukup, $+2=$ Rusak, $+1=$ Sangat Rusak 
Pada perlakuan kemasan plastik PP, rasa sangat baik sampai hari ke 5. Pada hari ke 10 nugget mulai mengalami kerusakan dimana rasa mulai mengalami perubahan tetapi kondisi ini nugget masih bisa dikonsumsi. Hari ke 15 nugget sudah mengalami kerusakan. Kerusakan pada pengemas PP ditandai dengan rasa nugget yang asin mulai menjadi kecut. Perlakuan plastik jenis PE nugget juga mengalami kerusakan pada hari ke 10. Rasa pada nugget berubah menjadi kecut dari rasa yang awalnya asin dan lembut. Kerusakan juga terjadi pada aroma nugget. Pada hari ke 10 aroma nugget pada perlakuan PP atau pun PE mengalami perubahan. Kerusakan pada aroma nugget ditandai dengan perubahan aroma dari beraroma khas ikan menjadi tengik.

Tekstur nugget pada perlakuan tanpa kemasan sangat baik pada hari ke 5. Namun, mulai menunjukkan kerusakan pada hari ke 10 yaitu nugget mulai mengeras pada permukannya, tetapi lunak pada bagian dalam. Sedangkan pada hari ke 15 nugget mulai keras.Perubahan tersebut di sebabkan karena kandungan air nugget yang menurun drastis. Terbukti pada hari ke 15-20 kadar air nugget sudah di bawah 15\% dan pada kondisi tersebut nugget sudah tidak layak di konsumsi. Sedangkan pada perlakuan kemasan PP dan PE, nugget memiliki tekstur yang sangat baik sampai hari ke15 yaitu kenyal dan lembut. Hari ke 20 penyimpanan, kemasan masih mampu mempertahankan tekstur dengan baik, namun pada kondisi ini nugget jenis PP sudah mulai lengket pada permukaan dan nugget jenis PE sudah mulai di tumbuhi jamur pada permukaan nugget.

Kemasan plastik terbukti mampu mempertahankan warna pada nugget. Perlakuan kemasan PE dan PP warna tetap cerah sampai hari ke 20 yaitu berwarna coklat. Sedangkan nugget tanpa pengemas kurang mampu mempertahankan warna nugget. Perubahan warna yang dialami nugget tanpa kemasan adalah dari coklat menjadi coklat tua.

\section{KESIMPULAN DAN SARAN}

\section{Kesimpulan}

Jenis pengemas plastik berpengaruh terhadap kadar air dan kadar protein nugget gembus. Lama penyimpanan juga memberikan pengaruh nyata pada kadar air dan kadar protein nugget gembus. Interaksi antara perlakuan jenis pengemas plastik dan lama penyimpanan juga berpengaruh nyata terhadap kadar air dan kadar protein nugget gembus

\section{Saran}

Diperlukan penelitian lebih lanjut untuk penelitian kandungan nugget gembus yang lainnya seperti kandungan lemak, karbohidrat dan kalsium.

Diperlukan penelitian lebih lanjut menggunakan bahan pengemas yang lain dan parameter suhu.

Diperlukan penelitian lebih lanjut tentang mengurangi kadar air nugget agar sesuai dengan SNI.

\section{DAFTAR PUSTAKA}

Agus D S; S. Kumalaningsih; A. Febrianto Mulyadi. 2013. Studi Stabilitas Pengangkutan Susu Segar Pada Suhu Rendah Yang Layak Secara Teknis Dan Finansial (Kajian Suhu Dan Lama Waktu Pendinginan). Jurnal penelitian. Jurusan Teknologi Indusri Pertanian Universitas Brawijaya

Creniewicz, M. 2006. Storage Stability of Raw Milk Subjected to Vibration. Polish Journal of National Science. Vol 15 pp $65-70$

Fajrin, A. M; K. Setyowati; A. Iskandar; Sugiarto; I. Yuliasih. 2000. Pengemasan 1. Teknologi Industri Pertanian. Institut Pertanian Bogor

Ginting, N. 2006. Penambahan Bahan Pengikat Pada Nugget Itik Serati (The Addition Of Binder Matter On Waterfowls Nugget). Jurnal Agribisnis Peternakan, Vol. 2, No. 1 
Istanti, I. 2005. Pengaruh Lama Penyimpanan Terhadap Karakteristik Kerupuk Ikan Sapu-Sapu (Hyposarcus pardalis). Skripsi. Teknologi Hasil Perikanan Fakultas Perikanan Dan Ilmu Kelautan Institut Pertanian Bogor

Latifah, N. H. 2010. Pemilihan Jenis Plastik dan Pembuatan Desain Kemasan untuk Keripik Tette Madura. Skripsi. Bangkalan: Teknologi Industri Pertanian Fakultas Pertanian Universitas Trunojoyo Madura

Marada, H. 2012. Pengaruh Lama Penyimpanan Ikan Cakalang Pada Suhu Freezer Terhadap Jumlah Bakteri. Skripsi. Jurusan Kesehatan Masyarakat Universitas Negeri Gorontalo
Mareta, D. T. dan S. Nur A. 2011. Pengemas Produk Sayuran Dengan Bahan Kemas Plastik Pada Penyimpanan Suhu Ruang Dan Suhu Dingin. Jurnal Mediagro. Vol 7. No 1. Hal 26-40

Sudarmadji, S; B, Haryono; Suhardi. 2013. Analisa Bahan Makanan dan Pertanian. Liberty Yogyakarta: Yogyakarta

Wulandari, A; S. Waluyo; D. D. Novita. 2013. Prediksi Umur Simpan Kerupuk Kemplang Dalam Kemasan Plastik Polipropilen Beberapa Ketebalan. Jurnal Teknik Pertanian Lampung. Vol. 2. No. 2:105-11 